\title{
Game theory in solving conflicts on local government level
}

\author{
Nikolina Žajdela Hrustek ${ }^{1, *}$, Nenad Perši ${ }^{1}$ and Dino Kliček ${ }^{1}$ \\ ${ }^{1}$ Faculty of Organization and Informatics \\ University of Zagreb, 42000 Varaždin, Croatia \\ E-mail: 〈\{nikolina.zajdela,nenad.persi\}@foi.unizg.hr $\rangle,\langle k l i c e k . d i n o @ g m a i l . c o m\rangle$
}

\begin{abstract}
Game theory is often used while making decisions in situations of conflicted interests. This research studies practical application of game theory with emphasis on applying linear programming, i.e. simplex algorithm while solving problems in game theory domain. Different cases of game theory application in various scientific disciplines went through theoretical analysis. After the analysis was conducted, this paper presented a practical example of solving a situation of conflict on local government level and the efficiency of game theory while making decision.
\end{abstract}

Keywords: game theory, linear programming, simplex algorithm, situation of conflict

Received: January 17, 2020; accepted: May 31, 2020; available online: July 07, 2020

DOI: $10.17535 /$ crorr.2020.0007

\section{Introduction}

Success in business surroundings subjected to constant changes relies greatly on well made decisions, which results in the fact that business decisions today are made in conditions of risk, insecurity and conflict, while the final result can cause certain gain or loss. Decision making process is always focused on maximization, in making the best possible decision in a specific situation, which consequently makes the consideration of all characteristics in a given situation while making a decision necessary. The mathematical-economical discipline called game theory was developed from monitoring different situations of conflict among people and organizations. Game theory is appropriate for application in various business and life situations, especially for analysis or making complex decisions in organization with purpose of reaching the outcome favorable for the person making the decision or the entire organization.

The structure of this paper is divided in two main parts, theoretical and practical. Following the introduction, theoretical part in the Section 2 presents review of relevant studies in game theory with application of matrix games while solving different types of business-like problems, but also situations in life. The Section 3 outlines basic theoretical propositions of linear programming, as well as simplex algorithm, with emphasis on applying linear programming and simplex algorithm in game theory. An example of a specific problem from the real system is described in the Section 4 which explains the procedure of determing the mathematical model of a real problem and its solving via simplex algorithm. Paper ends with the Section 5 which brings critical review and authors' discussion of presented research problem.

${ }^{*}$ Corresponding author.

http://www.hdoi.hr/crorr-journal

(C)2020 Croatian Operational Research Society 


\section{Game theory}

Game theory finds its application in various contexts, starting with everyday quarrels, making more or less important personal decisions and finishing with business decisions such as increase in production, product quality, etc. It refers to observing situations with two or more opposing parties where each party has certain understanding of the way their own but also the others move making influences the situation's final outcome. Game theory leads each player into choosing the best possible strategy in situations of competition or conflict [24]. The application of game theory itself is much wider owing to the capability of modeling conflicts and collaboration problems in fields of politics, economy, warfare to biology. Proportionately to this, as quoted in [15], Kelly divides game theory into three categories: games of skills, fortune games and strategic games. While using game theory in many scientific disciplines, many definitions of game theory appear. Each definition assumes the existence of a group of players, players activity intrapersonal interactions, players rationality, strategic ways of contemplating and making decisions and series of linked and conditioned moves made by the players, which makes developing one's own game strategy for the realization of set goals necessary [19].

\subsection{Types of games}

Types of games in game theory generally differ regarding the total number of players [22], which actually makes games with one player to be skill games and fortune games and not subject matter of game theory as such. Two or multiple players' games, with their main characteristic being strategic games and are as such the most common types of games studied by the game theory. Kopal and Korkut [15] differentiate strategic, extensive and coalitional forms of game. Strategic of normal form is characterized by the payoff matrix which presents the players, their strategies and payments for each strategy combination the players are awarded with after applying certain strategy. Extensive or sequential form of game is presented in form of a tree consisting of knots, lines and groups of outcomes. The coalitional game form is characterized by players or certain subgroup of players (coalition) reaching an agreement prior to the game on what they will do or want to achieve.

One of the most significant divisions of strategic games is division into cooperative and non-cooperative games. Strategic games, with the interests of two or more players coinciding, are called cooperative strategic games. Games without the collaboration among the players, i.e. each player autonomously chooses the strategy without coordinating it with other players, are called non-cooperative games. Game theory also considers games with existing conflicts, such games are called strategic games with zero total since one player's gain is another player's loss [15]. Great number of games relates to games with alterable total which are, unlike games with zero total, not strictly competitive due to the fact that they contain elements of collaboration since the outcome can be bad unless an agreement is not reached.

A significant game type represents games of mixed motives where players' interests do not correspond completely and simultaneously comprise elements of collaboration and noncollaboration. Such games are most commonly in the context of strategic games because they vividly present situations where one needs to make the best moves with regard to dependence on other players and restriction terms of the interest one wishes for [13]. According to Barković Bojanić and Ereš [2], games can be static and dynamic. In static games a player chooses strategy simultaneously with their opponents, which results in players not having information on strategies chosen by other players. On the other hand, dynamic games enable opponents to choose their strategies while already knowing the moves of the first player. Kapor [13] differentiates games with perfect and non-perfect information. In games with perfect information each player gets complete information on all moves played during the game. Otherwise, if complete information does not exist, one is talking about a game with non-perfect information. 


\subsection{Application of game theory}

Game theory has a rich and long history through its application in economics, political and social sciences, philosophy, biology, warfares and recently in area of computer science. Game theory registers its greatest usage in economical sciences. Brkić [4] analyses more examples of game theory application in international economics, starting with customs policies and customs unions, international cartels, extracting resources of common assets and finishing with international negotiations among individual countries. Lemaire [18] studies games usage with regards to dividing operative costs. This paper mentions a couple of efficient applications of solution concepts of games theory: tax division among subsidiaries in a corporation, costs division of property lease, financing big projects, subsidizing public transport etc. A specific example of game theory usage can be found in the paper "Support System Marketing to Making DecisionsBased on Game Theory" by authors Dukić, Turkalj and Sesar [8], which studies the choice of optimal strategy for product marketing. This is a common problem for the marketing area, especially in terms of competition and conflict situations. The paper presents a model of two opposing parties sharing the market of specific products. Both competitors' intention is to start a marketing campaign with goal of taking over their direct opponent's consumers. Each company has a certain number of strategies at their disposal, i.e. media to advertise their products. The paying matrix was formed based on estimated effects of all possible combinations of strategies on the percentage change of one player's market share. The effects of market changes were given by computer simulation of percentage changes which become elements of the below presented payment matrix with strategies of each company. After forming the payment matrix with simulated values of percentage changes in the market, the problem transformed itself into the model of linear programming, which resulted in providing results of probability of playing out certain strategies which ensure the achievement of the best possible outcome. A similar example of game theory usage usefulness while managing city transport can be seen in the paper "Role of Game Theory in Planning City Transport" by authors Pašagić, Škrinjar, Abramović and Brnjac [21]. To reach optimal decisions while organizing traffic, this research used, apart from simulation methods, methods of game theory for strategic decision making, too. Application of matrix games was presented with purpose of solving problems while choosing a site to build the city bus station. On the other side Ghani et. al. [11] introduce in the paper "Compositional Game Theory" how methods of game theory and theoretical computer science can be applied to large-scale economic models for which standard economic tools are not practical.

Besides economy, the most frequent use of game theory is visible in political and legal science. Politics uses game theory as analytical tool. In such theoretical game models players are countries, political parties, voters and other interest groups. Great attention is given to modeling collaboration and conflicts among politicians in times of election, but also while making important decisions in democracy [24]. Rationality of the players themselves has a great role in political sciences. Austen-Smith and Banks [1] consider relationships between collective preferences and non-cooperative approach while playing the games, where two basic models of rational players in politics are differentiated: players with direct choice preferences and players with indirect choice preferences. Collective decision is the consequence of firm decisions made by each player in a game based on their preferences. While modeling collective decisions, there is a need for good defining of possible events, complex surroundings and criteria of minimal democracy of each player. Furthermore, legal sciences also use game theory with purpose of understanding legal rules and institutions' procedures. In legal branches the most known and used game model is the prisoner's dilemma, which serves for illustrating various situations connected to human behavior. Barković Bojanić and Ereš [2] outline that precisely such game concept is often used in family law practice, i.e. in divorce problem area, while assigning alimony or dividing possessions during divorce. Furthermore, such game concept 
is also useful in constitutional law while voting in election and forming coalitions. Criminal law also uses such game concept with purpose of releasing or reducing sentence to drug cartel participants in an effort to extrude valuable information from the players. One can conclude that prisoner's dilemma concept paints numerous law situations and thus enables all participants to develop their own strategies and accomplish wanted results by using game theory.

Regarding the fact that game theory enables explaining, anticipating and estimating human behavior in different situations, it is significantly applied in philosophy, more precisely in ethics and political philosophy. Likewise, biology also uses games in order to explain the evolution of animals' social behavior and thus provide the answer to the question why not only animals, but people, too, collaborate. Human civilization rests on mutual collaboration and understanding without which it would not develop into what it represents today. Finding laws of nature which describe human behavior is enabled precisely by game theory [20].

Game theory models are becoming more common and used in the area of warring, in fighting against terrorism, as quoted by Fricker [10] in his paper "Game Theory in an Age of Terrorism: How Can Statisticians Contribute?" Using game theory can enable a different outlook on terrorism analysis based on strategic analyses. This paper quotes the way theoretical game methods provide a structured means of questioning the manner of country's response under different scenarios in conflicts with terrorists. Matrix games for studying terrorism include the use for: estimating strategies on the way countries assign money for terrorism and consequences in case of attack, measures that stimulate different war politics and strategies against terrorism, defining whether negotiating with terrorists while taking hostages is a better choice or not and under which circumstances. In such cases, matrix games most commonly consist of antiterrorist strategies (anticipation and diversion) and policies in case of stubborn and tenacious terrorists. The resulting interaction between terrorists and governments makes game theory a worthy tool for discovering all facts and possible anti-terrorist strategies. Synthesis of previously presented application leads to conclusion that game theory analyzes strategic interactions by using mathematical framework with purpose of providing optimal solution for individual player or all players (balance). Therefore, game theory places optimal strategies at disposal in order to materialize profit, but also to minimize loss.

Nowadays, there are many research studies in area of computer science which apply game theory. Liang and Xiao [19] discuss using game theory in network security in their paper "Game Theory for Network Security". As networks become omnipresent in people's lives, users daily continue to depend on them due to access to information and communication to others. However, computer networks daily receive security threats, especially attacks that cause great losses to users (privacy disruptions, personal data, finances, etc.). This paper studies in detail the application of matrix games via two categories, the one for general analysis of defending attacks and the other for specialized attack-defense analysis. Likewise, the payment matrix of defenders is presented regarding the malevolent attack by using Nash balance.

Roy et al. [25] conducted a research which is related to understanding game theory solutions to a variety of cyber security problems and proposes a taxonomy for classifying existing game theory which are designed to enhance network security. Concerning cyber security, Wang et al. [27] in his research paper describes a focused literature survey of game theoretic methods for cyber security applications. Charilas and Panagopoulos [6] investigate the existing game theory application results in the field of wireless network engineering. In the field of computer science game theory has been widely used also on the issue of distributed denial of service attacks $[3,23,28]$, as well as in area of cloud computing [5, 9, 17, 26, 29]. 


\section{Matrix game}

Strategic form is the most common game illustration which enables its mathematical representation via matrix. Adequately, such game adopts the name matrix game. The main feature of matrix games is payoff matrix, where strategies of one player are presented in matrix rows, while strategies of another player are in matrix columns. Likewise, it is characteristic for such form of presentation that all outcomes, i.e. payoff ways for any player strategy are known in advance [22].

\subsection{Reducing the game to a linear problem}

Linear programming represents a group of methods and actions whose main characteristic is universal application in various areas of science and social activities. Kreko [16] defines linear programming as a special case of programming when the objective function and its constraints can be expressed in linear mathematical relations. The problem of linear programming is based on linear objective function, and its constraints are expressed in form of linear equations or inequalities. As solution to linear programming problem, Kalpić and Mornar [12] say one needs to find extreme (minimum or maximum) for the given objective function consisting of structured variables with condition of satisfying all constraints on structured variables. Adequately, the objective function optimum is always found in the area defined by the system of linear equations and inequalities. Prior to one's beginning to reducing the game to its linear problem, one needs to define the payoff matrix.

\begin{tabular}{|c|cccc|}
\hline & \multicolumn{4}{|c|}{ Player B } \\
Player A & $y_{1}$ & $y_{2}$ & $\ldots$ & $y_{n}$ \\
\hline \hline$x_{1}$ & $a_{11}$ & $a_{12}$ & $\cdots$ & $a_{1 n}$ \\
$x_{2}$ & $a_{21}$ & $a_{22}$ & $\cdots$ & $a_{2 n}$ \\
$\vdots$ & $\vdots$ & $\vdots$ & $\ddots$ & $\vdots$ \\
$x_{m}$ & $a_{m 1}$ & $a_{m 2}$ & $\cdots$ & $a_{m n}$ \\
\hline
\end{tabular}

Figure 1: Payoff matrix

According to Figure 1, let us assume the existence of player A with strategies $i=1,2, \ldots, m$ and player B with strategies $j=1,2,3, \ldots, n$, both with defined payment methods of each player $a_{i j}$. Probability that player A will use strategy $i$ is given by $x_{i}$, while $y_{j}$ represents probability of player B using the strategy $j$. Regarding the probability of playing off individual strategy, each player determines their plan of playing the game. Players A and B determine their game plans by associating values to their strategies for which the terms are obligatory as follows:

$$
\begin{aligned}
& x_{i} \geq 0, \quad i=1,2, \ldots, m, \\
& y_{j} \geq 0, \quad j=1,2, \ldots, n, \\
& \sum_{i=1}^{m} x_{i}=1, \\
& \sum_{j=1}^{n} y_{j}=1 .
\end{aligned}
$$

By obtaining game plan $\left(x_{1}, x_{2}, \ldots, x_{m}\right)$ for player $\mathrm{A}$ and game plan $\left(y_{1}, y_{2}, \ldots, y_{n}\right)$ for player $\mathrm{B}$, one has gotten the so-called mixed strategies of mentioned players. 
During the game, each player randomly chooses a strategy out of the group of mixed strategies, i.e. based on probability distribution's movements. For the games with mixed strategies the players' expected gain is equal to:

$$
E(x, y)=\sum_{i=1}^{m} \sum_{j=1}^{n} x_{i} a_{i j} y_{j},
$$

where $a_{i j}$ is the win of individual player if player A plays the strategy $i$ and player B strategy $j$. Relation (2) is bilinear since it presents an average expected win for both players if the game is played multiple times. Player A chooses the optimal mix of strategies which ensures the greatest win (maximizes minimal expected win), regardless of which strategy player B uses. Value of expected win of such strategies for player A is called lower game value and is marked with $V_{A}$. On the other hand, player B will choose optimal strategy mix to ensure the least possible expected loss (minimizes maximal expected loss), regardless of which strategy player A uses. Such value is called upper game value and is marked with $V_{B}$ [20]. In this manner starting characteristics and constraints of matrix game are defined and need to be met from the linear programming perspective. In a mixed game of two players with total amount zero, the mixed strategy $\left(x_{1}, x_{2}, \ldots, x_{m}\right)$ of player $\mathrm{A}$ is optimal only if the expected players win, provided by relation (2), is greater or equal to its minimal expected win $V_{A}$ [20]. This is given in mathematical notation:

$$
\sum_{i=1}^{m} \sum_{j=1}^{n} x_{i} a_{i j} y_{j} \geq V_{A},
$$

for all mixed strategies $y_{1}, y_{2}, \ldots, y_{m}$ by player B. Relation (3) needs to have value for all strategies by player B. For example, for $\left(y_{1}, y_{2}, \ldots, y_{n}\right)=(1,0, \ldots, 0)$, one gets the following:

$$
\sum_{i=1}^{m}\left(\sum_{j=1}^{n} a_{i j} y_{j}\right) x_{i}=\sum_{i=1}^{m} a_{i 1} x_{i}=a_{11} x_{1}+a_{21} x_{2}+\cdots+a_{m 1} x_{m} \geq V_{A}
$$

By announcing all strategies by player B via relation (4), one gets the non-equation system as follows:

$$
\begin{aligned}
& a_{11} x_{1}+a_{21} x_{2}+\cdots+a_{m 1} x_{m} \geq V_{A} \\
& a_{12} x_{1}+a_{22} x_{2}+\cdots+a_{m 2} x_{m} \geq V_{A} \\
& \begin{array}{ccc}
\vdots & \vdots & \vdots
\end{array} \\
& a_{1 n} x_{1}+a_{2 n} x_{2}+\cdots+a_{m n} x_{m} \geq V_{A}
\end{aligned}
$$

However, system (5), representing constraints of linear programming problem, needs to have additional constraints to ensure that values $x_{1}, x_{2}, \ldots, x_{m}$ are probabilities. On account of this, constraints need to be added as relation (1) states. Adequately, any solution $\left(x_{1}, x_{2}, \ldots, x_{m}\right)$ satisfying set of constraints (1) and (5) becomes optimal mixed strategy for player A. While defining objective function, one starts with assumption that player A's objective is to maximize minimal win $V_{A}$, i.e. minimize value $\frac{1}{V_{A}}$ about equally via each available strategy along with set of constraints [7]. In that manner, in order to obtain optimal mixed strategies by player A, it is necessary to solve the following linear programming problem with objective function;

$$
Z=1 x_{1}+1 x_{2}+\cdots+1 x_{m} \rightarrow \min \rightarrow 1,
$$


with constraints conditions:

$$
\begin{aligned}
& a_{11} x_{1}+a_{21} x_{2}+\cdots+a_{m 1} x_{m} \geq V_{A} \\
& a_{12} x_{1}+a_{22} x_{2}+\cdots+a_{m 2} x_{m} \geq V_{A} \\
& \vdots \quad \vdots \quad \vdots \quad \vdots \\
& a_{1 n} x_{1}+a_{2 n} x_{2}+\cdots+a_{m n} x_{m} \geq V_{A} \\
& x_{i} \geq 0, \quad i=1,2, \ldots, m, \\
& \sum_{i=1}^{m} x_{i}=1 \text {, }
\end{aligned}
$$

Analogue to previous manner, matrix game is reduced to linear problem for player B. The continuation of this paper will present a specific example of a conflict situation from everyday life. Throughout the problem description, the game theory with strategies and playoff outcomes will be presented in form of a table. Furthermore, previously defined outcomes will be quantified via specific evaluation elements in order to see how much win or loss individual strategy brings to each player. In said manner a payoff matrix will be constructed as outline for reducing the game to its linear problem form. Simplex algorithm will be applied for problem solving. Finally, as result, one will determine optimal strategy mixes for each player that player A will use to maximize their win, i.e. player B will use to minimize possible loss.

\section{Solving situation of conflict on local government level}

\subsection{Research problem description}

Ministry of Environment Protection and Energetics in Croatia opened a public consultation on laws on water management area, but main changes are expected in extremely dispersed local water supply systems. Their number should reduce from current 180 to 40 at most. According to the new law, company Varkom in Varaždin County should take over all local water supply systems without public water supply system status.

An example of local supply system can also be studied in the area of town of Lepoglava with approximately 20 local water supply systems resulting in agreements and labor by the local population. According to the new law, company Varkom imposes its right to claim the already existing miles of pipeline. The strongest resistance to it is registered with the inhabitants of Lepoglava where the entire town area is covered by local water supply system. The inhabitants already pay the monthly price of approximately 13 EUR for the water costs.

On the other hand, the price of monthly charges should double after conducting integration of local water supply systems with the company Varkom. Reasons for this are added services of drainage and purification of waste water with different prices over Varaždin County agglomerations. Discontent of local population does not lie only in monthly utility charges' increase, but also in quality of local water which definitely exists, if compared to water distributed by Varkom. Company Varkom has always been open to collaboration while taking over local water supply systems, especially considering the costs ocurring alongside. Namely, company Varkom is allowed to release water from their pumping sites into small local water supply systems, especially if they are technically in working order. This is not the case in area of Lepoglava, which conditions building a new one, partially financed by town of Lepoglava.

Town of Lepoglava has no intentions of delivering communal goods to private capital's management. 
For the communal goods, like water in this case, it would be the most rightful thing to be managed by local community in the widest base, but it would also be according to some of the rules of profession and with full responsibility. One wishes to avoid privatization and monopoly of public companies that one wishes to quietly impose.

Among others, there are other solutions connected to this question, like founding one's own communal company by the town of Lepoglava and the attempt of suppressing possibilities of the town of Lepoglava's paying for the water supply system to company Varkom. In the previous description of conflict situation two players are visible, town of Lepoglava and company Varkom. Likewise, one can discern some possible strategies of each player. Player town of Lepoglava wishes to completely or partially keep the ownership over water supply systems, create a new company in charge of communal business (create new jobs, increase inhabitants' satisfaction), and leave an approximate amount of payments that citizens currently have. On the other hand, company Varkom wants to claim ownership over local water supply systems, their new users and expand the market, which enables creation of a monopolistic situation in this region (possibility of increasing costs of services). Figure 2 in continuation describes and quantifies gains and losses for each player placed in interacting relationship.

\begin{tabular}{|lrl|}
\hline Town of Lepoglava Gains: & Varkom Inc. Losses: \\
\hline \hline $\begin{array}{l}\text { Maintaining ownership over citizens' } \\
\text { water supply system }(+1)\end{array}$ & $\begin{array}{l}\text { Impossibility of business expansion over } \\
\text { Lepoglava's water supply systems }(-1)\end{array}$ \\
\hline $\begin{array}{l}\text { Maintaining number of water supply } \\
\text { systems (+1) }\end{array}$ & $\begin{array}{l}\text { Impossibility of manipulating other people's } \\
\text { water supply systems }(-1)\end{array}$ \\
\hline $\begin{array}{l}\text { Maintaining citizens' number in current } \\
\text { water supply system (+1) }\end{array}$ & $\begin{array}{l}\text { Lack of new number of users } \\
\text { (attachments) }(-1)\end{array}$ \\
\hline $\begin{array}{l}\text { New communal company (new jobs } \\
\text { for citizens) }(+1)\end{array}$ & $=\begin{array}{l}\text { Manifestation of new competition in the } \\
\text { market - lack of monopoly creation }(-1)\end{array}$ \\
\hline $\begin{array}{l}\text { Maintaining approximate current prices } \\
(+1)\end{array}$ & $=\begin{array}{l}\text { Without monopoly, one loses the possibility } \\
\text { of increase in prices }(-1)\end{array}$ \\
\hline
\end{tabular}

Figure 2: Possible gains and losses of each player

Game problem presented in Figure 2 makes this game zero amount game where one player's win is equal to another player's loss. Nine outcomes, as consequences of each player's possible choice of individual strategies, are presented and described in the Figure 3. As possible strategies, town of Lepoglava has developed a possibility of founding communal company called Lepkom, completely independent of company Varkom, and be its competition. Also, Lepoglava will lean on its citizens to stand in the way of Varkom's takeover of water supply system. There is also an option of doing absolutely nothing, i.e. surrendering the entire situation to citizens. On the other hand, player company Varkom has a strategy of hostile takeover of water supply system at its disposal, since it can be done according to the new law. Specific quality of this game lies partially in possible distributive negotiation, which will create a win-lose situation, where one party will win while another one will lose. Varkom can negotiate with town of Lepoglava since it is not the owner of the existing infrastructure where it plans to distribute the water and, with these negotiations, it wishes to avoid additional necessary expansion of existing infrastructure, which would result in great costs. This would make town of Lepoglava a loser and company Varkom a winner. The third possible strategy is escaping the law, i.e. fulfilling law formalities without interest in any significant investments in Lepoglava's water supply systems. 


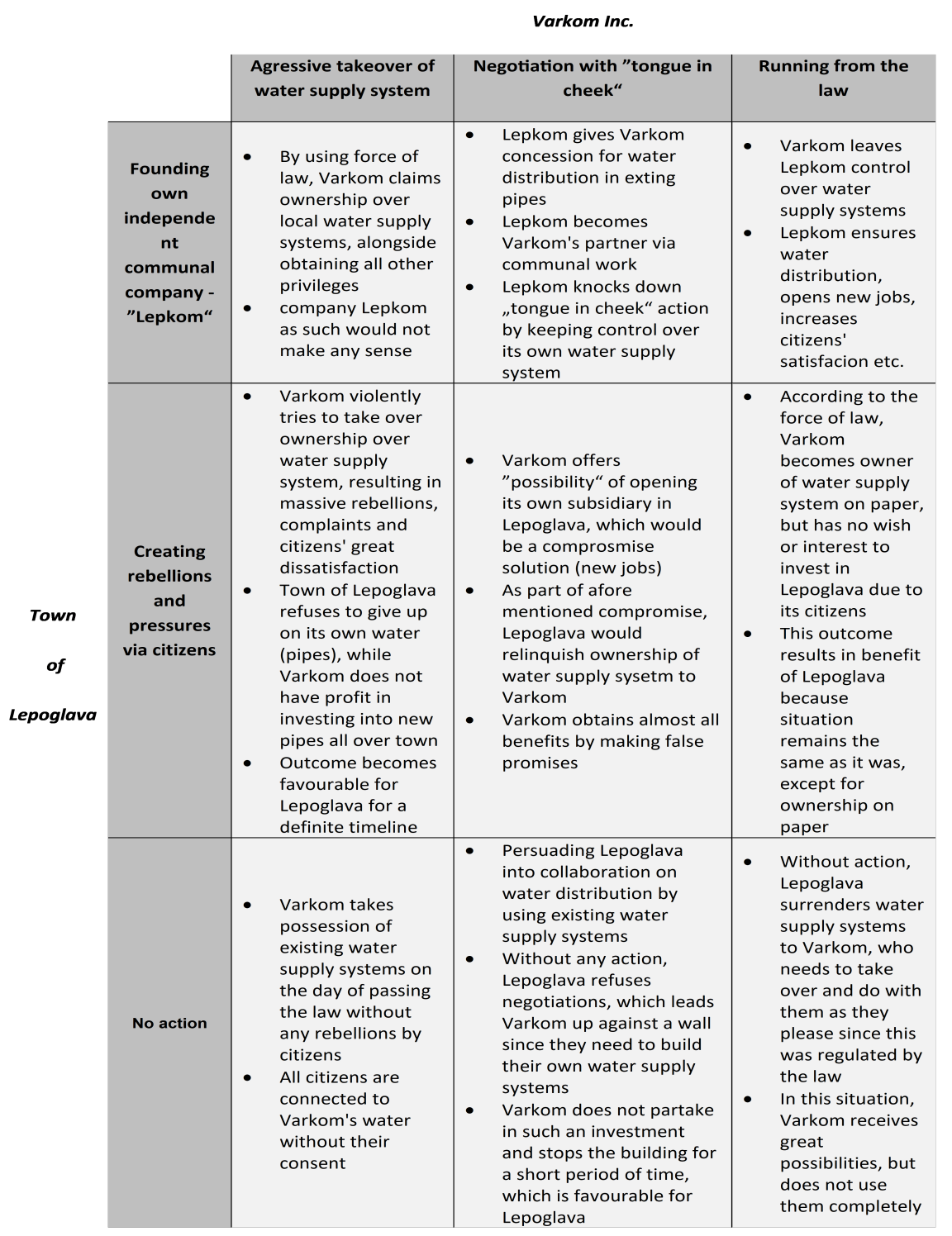

Figure 3: Description of consequences for strategies chosen for Lepoglava and company Varkom

The previous figure provides the context of possible events and represents the first step in determining the payment matrix of a game. The results described above need to be viewed from the perspective of all five gains and losses in Figure 2 in order to accurately determine the gains and losses of each player. Therefore, in the case of aggressive takeover of water supply, the town of Lepoglava, with the strategy of establishing its own company, would make a loss in the amount of -5 . The same loss would occur if Lepoglava does not take any action. Varkom would not benefit from an aggressive strategy if there were riots of citizens. In that situation, Lepoglava would preserve the ownership of the water supply system, the number of water supply systems and its users, but without the new company and current prices. So, the price would increase because the new law prescribes new measures for the maintenance of the water supply system, which are not currently being implemented, but which entails the necessary additional funds. Consequently, Lepoglava would make a profit in the amount of 3. 
Furthermore, by using the negotiation strategy, Varkom incurs a loss if the City of Lepoglava establishes its own company. Such situation would give the City of Lepoglava new jobs and the preservation of ownership over water supply systems would be achieved. Working together with Varkom would require certain compromises, such as increasing the price, but also shutting down unprofitable water supply systems and neglecting a certain number of citizens on those water supply systems. The town of Lepoglava makes a profit of 2, while a profit of 1 would be made if no action is taken. The main goal in Varkom's negotiations is to secure at least a minimum amount of money from the self government to realize the project. Without support, Varkom would give up the project and the ownership of the water supply system would remain intact, which brings minimal profit to Lepoglava. The reason for the minimal gain of this situation is due to citizens turning their backs on the town of Lepoglava and their cessation of water payments, i.e. the privatization of water supply and the determination of the number of citizens on certain water supply. The negotiation strategy would bring Varkom a profit only in case if Lepoglava accepts the opening of a communal branch with the hope of employing the citizens themselves. Such a situation would allow Varkom to expand its business, manipulate water utilities, increase the number of new users and ultimately increase service prices. In that case, Varkom would make a profit in the amount of 4 .

In the remaining situations, Varkom with the strategy of escaping from the law would turn out as a loser if Lepoglava chose the strategy of defense or rebellion. By founding a new company as a strategy of defense, Lepoglava would achieve all the gains listed in Figure 2, which is equal to 5. Escape from the law would bring Varkom a loss in the amount of 4 if the new laws explicitly require his ownership over the water supplies. Due to the revolt of the citizens, Varkom would not have any interest and desire for these waterworks, while Lepoglava should establish its own company and dispose of all benefits through the concession. Using a strategy of not taking any action, the town of Lepoglava would, according to the new law and the competent high authorities, ensure a loss of 3. The reason for this lies in Varkom's ownership of waterworks and its possible manipulation with prices and the creation of a monopoly.

Previously described game now can be easily transformed into payoff matrix considering the outcomes emerging from choosing individual strategies. The next payoff matrix consists of evaluated numeric value (players' payoff) joined to every possible outcome of this game.

\begin{tabular}{|c|ccc|}
\hline & \multicolumn{3}{|c|}{ Varkom Inc. } \\
Town of Lepoglava & Hostile takeover & Negotiation & Escaping the law \\
\hline \hline Defense & -5 & 2 & 5 \\
Rebellions & 3 & -4 & 4 \\
No action & -5 & 1 & -3 \\
\hline
\end{tabular}

Figure 4: Payoff matrix

Based on the created payoff matrix, an optimal mixed strategy of this game's players will be determined by using linear programming and simplex algorithm. In the continuation of this paper, it will be determined which strategies each player will have to lean on in order to acquire maximum win, i.e. minimum loss, considering the defined strategies and their possible gains and losses.

\subsection{Development of linear programming model}

Solving a previously set matrix game via linear programming with help of simplex algorithm starts by first reducing the matrix game to a linear problem. In this case, game will be reduced 
to a problem of maximum which corresponds to player B, i.e. company Varkom. This is due to easier tracking of defined mathematical relations in the subchapter that deals with reducing the game to a linear problem. In the beginning, matrix game (4) is reduced to its standard form as follows:

$$
Z=1 y_{1}+1 y_{2}+1 y_{3} \rightarrow \max \rightarrow 1
$$

with constraints conditions:

$$
\begin{aligned}
-5 y_{1}+2 y_{2}+5 y_{3} & \leq V_{B} \\
3 y_{1}-4 y_{2}+4 y_{3} & \leq V_{B} \\
-5 y_{1} & +1 y_{2}-3 y_{3} \leq V_{B} \\
y_{i} & \geq 0, \quad i=1,2,3 .
\end{aligned}
$$

In the previous note of standard problem, it is visible that, while creating limitation, player B takes values from payoff matrix rows. Since payoff matrix contains negative elements or players' payoffs, difference needs to be added. In this problem, difference $(d)$ is 6 in order for the lowest value of payoff matrix elements $(-5)$ to become positive. Difference is also added to other payoff matrix elements, which results in other negatives becoming positive. After adding difference, marking $y_{i}$ changes into $y_{i}^{\prime}$ and marking $V_{B}$ into $V_{B}^{\prime}$. This results in problem with difference as follows:

$$
Z=1 y_{1}^{\prime}+1 y_{2}^{\prime}+1 y_{3}^{\prime} \rightarrow \max \rightarrow 1
$$

with constraints conditions:

$$
\begin{gathered}
1 y_{1}^{\prime}+8 y_{2}^{\prime}+11 y_{3}^{\prime} \leq V_{B}^{\prime} \\
9 y_{1}^{\prime}+2 y_{2}^{\prime}+10 y_{3}^{\prime} \leq V_{B}^{\prime} \\
1 y_{1}^{\prime}+7 y_{2}^{\prime}+3 y_{3}^{\prime} \leq V_{B}^{\prime} \\
y_{i}^{\prime} \geq 0, \quad i=1,2,3 .
\end{gathered}
$$

In order for the presented problem to be suitable for appropriate simplex algorithm, it needs to contain certain value after the marking " $\leq$ ". This is accomplished by multiplying all inequalities with $\frac{1}{V_{B}^{\prime}}$, which results in obtaining final note of difference problem form for the second player (company Varkom) as follows:

$$
Z=\frac{y_{1}^{\prime}}{V_{B}^{\prime}}+\frac{y_{2}^{\prime}}{V_{B}^{\prime}}+\frac{y_{3}^{\prime}}{V_{B}^{\prime}} \rightarrow \max \rightarrow \frac{1}{V_{B}^{\prime}}
$$

with constraints conditions:

$$
\begin{aligned}
& 1 \frac{y_{1}^{\prime}}{V_{B}^{\prime}}+8 \frac{y_{2}^{\prime}}{V_{B}^{\prime}}+11 \frac{y_{3}^{\prime}}{V_{B}^{\prime}} \leq 1 \\
& 9 \frac{y_{1}^{\prime}}{V_{B}^{\prime}}+2 \frac{y_{2}^{\prime}}{V_{B}^{\prime}}+10 \frac{y_{3}^{\prime}}{V_{B}^{\prime}} \leq 1 \\
& 1 \frac{y_{1}^{\prime}}{V_{B}^{\prime}}+7 \frac{y_{2}^{\prime}}{V_{B}^{\prime}}+3 \frac{y_{3}^{\prime}}{V_{B}^{\prime}} \leq 1 \\
& \frac{y_{i}^{\prime}}{V_{B}^{\prime}} \geq 0, \quad i=1,2,3 .
\end{aligned}
$$


For later easier orientation and calculation, substitution of all values $\frac{y_{i}^{\prime}}{V_{B}^{\prime}}$ with $\bar{y}_{i}$ is performed in previously written difference problem form, which results in substituted problem form as follows:

$$
Z=\bar{y}_{1}+\bar{y}_{2}+\bar{y}_{3} \rightarrow \max \rightarrow \frac{1}{V_{B}^{\prime}}
$$

with constraints conditions:

$$
\begin{gathered}
1 \bar{y}_{1}+8 \bar{y}_{2}+11 \bar{y}_{3} \leq 1 \\
9 \bar{y}_{1}+2 \bar{y}_{2}+10 \bar{y}_{3} \leq 1 \\
1 \bar{y}_{1}+7 \bar{y}_{2}+3 \bar{y}_{3} \leq 1 \\
\bar{y}_{i} \geq 0, \quad i=1,2,3 .
\end{gathered}
$$

Finally, all that remains is converting substituted form into extended (canon) problem form. Simultaneously, this is a condition which enables simplex algorithm application. Slack variables $u_{i}, \quad i=1,2, \ldots, m$, are added to substituted form in order to transform non-equations into equations. The addition results in extended (canon) problem form as follows:

$$
Z=\bar{y}_{1}+\bar{y}_{2}+\bar{y}_{3}+0\left(u_{1}+u_{2}+u_{3}\right) \rightarrow \max \rightarrow \frac{1}{V_{B}^{\prime}}
$$

with constraints conditions:

$$
\begin{aligned}
& 1 \bar{y}_{1}+8 \bar{y}_{2}+11 \bar{y}_{3}+u_{1}=1 \\
& 9 \bar{y}_{1}+2 \bar{y}_{2}+10 \bar{y}_{3}+u_{2}=1 \\
& 1 \bar{y}_{1}+7 \bar{y}_{2}+3 \bar{y}_{3}+u_{1}=1 \\
& \bar{y}_{i} \geq 0, \quad i=1,2,3 . \\
& u_{j} \geq 0, \quad j=1,2,3 .
\end{aligned}
$$

By obtaining extended (canon) problem form, reducing the game to a more acceptable form of linear programming for further use of simplex algorithm is finished.

\subsection{Results}

After conducting simplex procedure, results were acquired as follows: optimal game value determines the winner of the game. In this problem its amount is -1, meaning the winner of the game is the player Varkom. To realize this game at its advantage, player company Varkom, based on results acquired, needs to use the first strategy $\left(y_{1}\right)$ in the percentage of $42.86 \%$. Likewise, the second strategy $\left(y_{2}\right)$ needs to be used with probability of $57.14 \%$, while the third strategy $\left(y_{3}\right)$ should not be played at all. On the other hand, player Lepoglava should combine playing off the first $\left(x_{1}\right)$ and the second $\left(x_{2}\right)$ strategy with equal amount of probability of $50 \%$ to minimize its loss. Simultaneously, Lepoglava should not use the third strategy $\left(x_{3}\right)$. Based on previously acquired results, one can ask the question on what do given amounts specifically mean for each player in reality. According to previously acquired results, company Varkom should mostly use negotiation strategies which would help outplay Lepoglava and realize benefits. Likewise, along with negotiation strategy, it is often quite necessary to use the aggressive strategy of taking over water supply system, which the new law will allow to do. With goal of resisting Varkom's strategies, town of Lepoglava needs to equally consider using the strategy of opening one's own communal company, Lepkom, as well as strategies that 
will, alongside with citizens' help, create rebellion, complaints and pressure. Nevertheless, the final value of the game says that, with such set game settings, the winner would be company Varkom. This is a realistic result considering the fact that the new law will favor company Varkom more than town of Lepoglava. According to this game, company Varkom will, in case Lepoglava equally plays the above mentioned strategies, realize minimal gain - most probably only in form of ownership over water supply systems without any further rights.

Namely, by issuing the law on local water supply systems, Lepoglava and its citizens will find themselves in a losing only position. Game theory helps Lepoglava lose with the smallest possible difference, i.e. lose as little as possible. Precisely this is registered in the game value -1, which could have been -5 in Varkom's advantage. This problem presents great possibilities of applying, as well as usefulness of game theory in solving real life problems.

\section{Conclusion}

Regardless of type of conflict or number of conflicted parties, game theory presents mathematical model for calculating possible outcomes of strategies in decision making process. In this manner, game theory as a method, especially via matrix game, provides formal base in the process of deciding on evaluating individual strategies, as well as evaluating final possible outcome. Special importance of possibilities of formalizing conflict models is reflected on strategic level of deciding which, by making productive decisions, crucially affects the processes in business surroundings. The described example of game theory application presents competition among business subjects that choose a strategy at the same time and do not know the information about the chosen strategy of another business entity, i.e. player. So, that game is described as a static type of game where players choose their strategies based on expectations of what will play other players. It is, therefore, most important for each player to identify all elements of games, consider how to act when information about the strategies of the other player would be known and at the end to determine their most dominant strategy. By defining influential elements and estimating their importance within law and market frameworks, one defines the conflict the solution of which demands making strategic decisions in business subjects. Final outcome presents possible strategies and their values as patterns of conduct for all participants of conflict situation. According to these available strategies, the win of conflicted business subjects is maximized, i.e. the loss is minimized.

\section{References}

[1] Austen-Smith, D. and Banks, J. S. (1998). Social choice theory, game theory and positive political theory. Annual Review of Political Science, 1(1), 259-287. doi: 10.1146/annurev.polisci.1.1.259

[2] Barković Bojanić, I. and Ereš, M. (2013). Teorija igara i pravo. Pravni vjesnik: časopis za pravne $i$ društvene znanosti Pravnog fakulteta Sveučilišta J.J. Strossmayera u Osijeku, 29(1), 59-76. https: $/ /$ hrcak.srce.hr/111004

[3] Bedi, H., Shiva, S. and Roy, S. (2014). A game inspired defense mechanism against distributed denial of service attacks. Security and Communication Networks, 7(12), 2389-2404. doi: $10.1002 / \mathrm{sec} .949$

[4] Brkić, L. (2002). Temeljni concept i teorije igara u međunarodnoj ekonomiji. Politička misao: časopis za politologiju, 39(3), 75-87. https://hrcak.srce.hr/23676

[5] Cardellini, V., Di Valerio, V. and Lo Presti, F. (2020). Game-theoretic resource pricing and provisioning strategies in cloud systems. IEEE Transactions on Services Computing, 13(1), 86-98. doi: 10.1109/tsc.2016.2633266

[6] Charilas, D. E. and Panagopoulos, A. D. (2010). A survey on game theory applications in wireless networks. Computer Networks, 54(18), 3421-3430. doi: 10.1016/j.comnet.2010.06.020

[7] Dobrenić, S. (1978). Operativno istraživanje. Varaždin: Viša ekonomska škola. 
Nikolina Žajdela Hrustek, Nenad Perši and Dino Kliček

[8] Dukić, G., Turkalj, D. and Sesar, M. (2008). Sustav podrške marketing-odlučivanju baziran na teoriji igara. Ekonomski vjesnik: Review of Contemporary Entrepreneurship, Business and Economic Issues, 21(1-2), 75-81. https://hrcak.srce.hr/42718

[9] Ficco, M., Esposito, C., Palmieri, F. and Castiglione, A. (2018). A coral-reefs and game theorybased approach for optimizing elastic cloud resource allocation. Future Generation Computer Systems, 78(1), 343-352. doi: 10.1016/j.future.2016.05.025

[10] Fricker, R. D. (2006). Game theory in an age of terrorism: How can statisticians contribute? In Wilson, A. G., Wilson, G. D. and Olwell, D. H. (Eds.), Statistical Methods in Counterterrorism (pp. 3-7). New York: Springer. doi: 10.1007/0-387-35209-0_1

[11] Ghani, N., Hedges, J., Winschel, V. and Zahn, P. (2018). Compositional game theory. Proceedings of the 33rd Annual ACM/IEEE Symposium on Logic in Computer Science, 472-481. doi: $10.1145 / 3209108.3209165$

[12] Kalpić, D. and Mornar, V. (1996). Operacijska istraživanja. Zagreb: Zeus.

[13] Kapor, P. (2017). Teorija igara: sistemski pristup i razvoj. Megatrend Review, 14(1), $153-282$. https://scindeks-clanci.ceon.rs/data/pdf/1820-3159/2017/1820-31591701253K.pdf

[14] Kopal, R. and Korkut, D. (2011). Teorija igara-praktična primjena u poslovanju. Zagreb: Lider Press d.d.

[15] Kopal, R., and Korkut, D. (2016). Uvod u teoriju igara. Zagreb: Visokoučilište Effectus-visoka škola za financije i pravo.

[16] Kreko, B. (1966). Linearno programiranje. Beograd: Savremena administracija.

[17] Künsemöller, J. and Karl, H. (2012). A game-theoretical approach to the benefits of cloud computing. In Vanmechelen, K., Altmann, J. and Rana, F. R. (Eds.), Economics of Grids, Clouds, Systems and Services (pp. 148-160). Berlin: Sringer. doi: 10.1007/978-3-642-28675-9_11

[18] Lemaire, J. (1984). An Application of Game Theory: Cost Allocation. ASTIN Bulletin, 14(1), 61-81. doi: 10.1017/s0515036100004815

[19] Liang, X. and Xiao, Y. (2013). Game Theory for Network Security. IEEE Communications Surveys and Tutorials, 15(1), 472-486. doi: 10.1109/surv.2012.062612.00056

[20] Neralić, L. (2003). Uvod u matematičko programiranje 1. Zagreb: Element.

[21] Pašagić Škrinjar, J., Abramović, B. and Brnjac, N. (2015). The use of game theory in urban transport planning. Tehnički Vijesnik-Technical Gazette, 22(6), 1617-1621. doi: 10.17559/tv20140108101820

[22] Petrić, J. (1979). Operaciona istraživanja (5. izdanje). Beograd: Savremena administracija.

[23] Poisel, R., Rybnicek, M. and Tjoa, S. (2013). Game-based simulation of Distributed Denial of Service (DDoS) attack and defense mechanisms of Critical Infrastructures. IEEE 27th International Conference on Advanced Information Networking and Applications (AINA), 114-120. doi: 10.1109/aina.2013.66

[24] Roljić, L. (2017). Reafirmacija praktične primjenjivosti teorije igara. Primus Global: naučno stručni časopis, $3(1)$.

[25] Roy, S., Ellis, C., Shiva, S., Dasgupta, D., Shandilya, V. and Wu, Q. (2010). A survey of game theory as applied to network security. IEEE 43rd Hawaii International Conference on System Sciences, 1-10. doi: 10.1109/hicss.2010.35

[26] Shi, B., Huang, Y., Wang, J. and Xiong, S. (2016). A game-theoretic analysis of pricing strategies for competing cloud platforms. IEEE 22nd International Conference on Parallel and Distributed Systems (ICPADS), 653-660. doi: 10.1109/icpads.2016.0091

[27] Wang, Y., Wang, Y., Liu, J., Huang, Z. and Xie, P. (2016). A survey of game theoretic methods for cyber security. IEEE First International Conference on Data Science in Cyberspace (DSC), 631-636. doi: 10.1109/dsc.2016.90

[28] Yan, G., Lee, R., Kent, A. and Wolpert, D. (2012). Towards a bayesian network game framework for evaluating DDoS attacks and defense. Proceedings of the 2012 ACM Conference on Computer and Communications Security, 553-566. doi: 10.1145/2382196.2382255

[29] Yuan, X., Min, G., Yang, L. T., Ding, Y. and Fang, Q. (2017). A game theory-based dynamic resource allocation strategy in geo-distributed datacenter clouds. Future Generation Computer Systems, 76, 63-72. doi: 10.1016/j.future.2017.04.046 